\title{
Introduction: The Economic Turn and Modern Russian History
}

\author{
Anna Krylova \\ Associate Professor of History, Department of History, Duke University, \\ Durham, NC USA \\ anna.krylova@duke.edu \\ Elena Osokina \\ Professor of History, Department of History, University of South Carolina \\ Columbia, SC USA \\ osokina@mailbox.sc.edu
}

The revival of academic interest in economic history and the analytics that the field has to offer to historians perhaps could have been predicted. Initiating a conversation about the conceptual currency of socio-economic methodologies, a number of scholars have pointed out that the protracted global economic crisis has once again rendered the invisible visible - that is, made the power of invisible economic dynamics to structure our everyday existence vividly real and undeniable. ${ }^{1}$ The prominent academic approach of the past three decades that declared everything and everyone "culturally constructed" and encouraged scholars to shift their agendas to the questions of representation has been proven ill-equipped to handle these pressing questions of socioeconomic processes that are changing our lives and, surely, have not spared the lives of our historical subjects in the past.

In the field of modern Russian history, the limits of cultural analysis are felt particularly acutely as scholars shift their attention to the postwar, and especially, post-1950s period and reach out into the present. In striking contrast with the thriving and, for the last three decades, sidelined research on socio-economic transformations of the prewar decades, the post-1950s years constitute largely an uncharted territory. Thus, the persistent efforts of socioeconomic historians of several generations working on the margins of the profession have ensured that we possess a rich corpus of scholarship on the

1 See, for example, Andrew Sloin and Oscar Sanchez-Sibony, "Economy and Power in the Soviet Union, 1917-39," Kritika: Explorations in Russian and Eurasian History, 15, 1 (Winter 2014), 7. 
making of the Soviet economic model of the prewar period. Our knowledge has been shaped by such classics as the works of E.H. Carr, Eugene Zaleski, R.W. Davies, Mark Harrison, Alec Nove, and Paul R. Gregory. ${ }^{2}$ Perhaps most importantly, the research on prewar socio-economic history has not lost its momentum since its founding decades and is presently engaged in a number of vibrant debates about the financial sources of Stalinist industrialization; the role of the collectivization and the GULAG system in the industrial push forward; the effectiveness of the emergent Soviet economy. ${ }^{3}$ More conceptual questions pertaining to the nature of the prewar economic system itselfwhat we call that which was being build in the 1930s? Was it socialist? statesocialist? state-capitalist? - are also coming under historians' consideration. ${ }^{4}$

It is this established and thriving research on the prewar period that underlines the underdeveloped state of economic scholarship on the postwar years, if, of course, one does not count the popular "stagnation" and "static" metaphors as satisfactory explanatory frameworks for understanding the late Soviet

2 E.H. Carr and R.W. Davies, Foundations of the Planned Economy, 1926-1929, 2 volumes (London: Macmillan, 1969); Eugene Zaleski, Planning for Economic Growth in the Soviet Union, 1918-1932 (Chapel Hill: University of NC Press, 1971); Eugene Zaleski, Stalinist Planning for Economic Growth, 1933-1952 (Chapel Hill: University of NC Press, 1980); R.W. Davies, The Socialist Offensive (Cambridge, Mass.: Harvard Univrsity Press, 1980); Paul R. Gregory and Robert C. Stuart, Soviet Economic Structure and Performance (New York: Harper \& Row, 1986); W. Davies, The Soviet Economy in Turmoil, 1929-1930 (Cambridge, Mass.: Harvard University Press, 1989); Alec Nove, An Economic Hidtory of the USSR (London: Penguin Books, 1990); R.W. Davies, Crisis and Progress in the Soviet Economy, 1931-1933 (Basingstoke and London; Macmillan Press, 1996); R.W. Davies, Mark Harrison, and S.G. Wheatcroft, eds., The Economic Transformation of the Soviet Union, 1913-1945 (Cambridge: Cambridge University Press, 1994).

3 А.А. Барсов, Баланс стоимостных обменов между городом и деревней (Москва: Наука, 1969) (Barsov A.A. Balans stoimostnykh obmenov mezhdu gorodom i derevnei. Moscow: Nauka, 1969); James Millar, "Mass Collectivization and the Contribution of Soviet Agriculture to the First Five-Year Plan," review article, Slavic Review, vol. 33 (1974), pp. 750-76o; Ellman Michael, "Did the Agriculture Surplus Provide the Resources for the Increase in Investment in the USSR During the First Five Year Plan?" Economic Journal, vol. 85 (1975), pp. 844-863; Alec Nove, and David Morrison, "The Contribution of Agriculture to Accumulation in the 1930s," in Charles Bettelheim, ed., L'Industrialisation de l'URSS dans les années trente (Paris: Editions de École des hautes études en sciences sociales 1982), pp. 47-63; R.W. Davies, Mark Harrison, and S.G. Wheatcroft, eds., The Economic Transformation of the Soviet Union, 1913-1945 (Cambridge: Cambridge University Press, 1994); Robert C. Allen, Farm to Factory: A Reinterpretation of the Soviet Industrial Revolution (Princeton University Press, 2003); Paul R. Gregory and V.V. Lazarev, eds., The Economics of Forced Labor: The Soviet Gulag (Stanford: Hoover Institution Press, 2003) and others.

4 See, for example, Andrew Sloin, "Theorizing Soviet Antisemitism: Value, Crisis, and Stalinist 'Modernity," Critical Historical Studies, vol. 2 (2016). 
period and contemporary Russian society. ${ }^{5}$ Recently defended dissertations and research in progress on postwar Soviet agriculture, the financial system, the 1965 and Perestroika economic reforms mark a critical turning point-the de-marginalization of socio-economic history, the trend to which this SPSR issue contributes. ${ }^{6}$

Contributors to the issue cover the economic longue durée of the Soviet century and its aftermath, deepening existing research agendas and articulating new ones. Thus, they continue to explore the nature of the Stalinist economy; delineate lacunas and deficiencies in our knowledge of post-1950s socio-economic trends and the mechanisms of their malfunctioning; as well as propose new conceptual approaches to rethinking Soviet Union's postwar and post-Soviet economic development and its imprint on people's experience of Soviet socialism and, later, capitalism. In respect to the post-195os decades in particular, the issue begins to fill up the socio-economic context of the period with the material circumstances of living (such as, for example, the dates and scope of the actual construction and workings of the Soviet welfare system) without which an interpretation of cultural sources is invariably impaired. Both contributors and editors hope to posit a crucial question about different methodological approaches within the subfields of economic, social, intellectual and cultural histories and call for a necessary analytical borrowing among the subfields.

5 Moshe Lewin's work on socio-economic, demographic, and cultural dimensions of the postwar period as well as Stephen Hanson's work on Marxism and Soviet economic institutions have been important exceptions to the rule, see Moshe Lewin, Political Undercurrents in Soviet Economic Debates: From Bukharin to the Modern Reformers (Princeton: Princeton University Press, 1974); Moshe Lewin, The Gorbachev Phenomenon. A Historical Interpretation (Berkeley: University of California Press, 1988); Stephen E. Hanson, Time and Revolution: Marxism and the Design of Soviet Institutions, (Chapel Hill: University of North Carolina Press, 1997).

6 See Christopher Miller, The Struggle to Save the Soviet Economy: Mikhail Gorbachev and the Collapse of the USSR (University of North Carolina Press, 2016); Kristy Ironside, "The Value of a Ruble: A Social History of Money in Postwar Soviet Russia, 1945-1964” (Doctoral Dissertation, University of Chicago, 2014); Aaron Hale-Dorrell, "Khrushchev's Corn Crusade: The Industrial Ideal and Agricultural Practice in the Era of Post-Stalin Reform, 1953-1964" (Doctoral Dissertation, University of North Carolina at Chapel Hill, 2014); Sara Brinegar, "Baku at all Costs: The Politics of Oil in the New Soviet State" (Doctoral Dissertation, University of Wisconsin-Madison, 2014); Patryk Reid, "Managing Nature, Constructing the State: The Material Foundation of Soviet Empire in Tajikistan, 1917-1937" (Doctoral Dissertation, University of Illinois-Urbana-Champaign, 2016); Yakov Feygin, "Building a Ruin: Economic Thought and the Politics of Soviet Reform 1955-1990" (Doctoral Dissertation, University of Pennsylvania, 2016). 
In "Everyday Shipping: A Market in Early Soviet Tajikistan," Patryk Reid deepens our understanding of the 1930 s economic landscape by joining the critics of the still prevalent view of the Stalinist economy as centralized, command, non-capitalist and, for these reasons, "marketless." He argues that if we shift our research emphasis from "products, industries, [and] statistical inputs and output" to what he calls the "operational" level, that is, the level of lived economic relations, we will find that market activities and relationships outside the plan were instrumental for building the economic structure that today we call centralized and command. Reid's case study focuses on freight transportation practices in southern Tajikistan during the First Five Year Plan which allows him to demonstrate how "semi-official" markets for shipping serviced came to life because of the infrastructural underdevelopment of the region and how they "drove economic life in the republic's southern regions in the early 1930s." Reid is careful to foreground the existence of markets and market activities in early Soviet Tajikistan and, at the same time, not to re-categorize the emergent economic system as a market system.

The next contribution, an article by the Vologda historians, Mikhail Beznin and Tatyana Dimoni, continues a discussion of the nature of the Soviet economy by analyzing the making and transformation of the Stalinist and post-Stalinist agrarian system. In their "Госкапитализм, социальные классы, культурный ландшафт советской деревни сталинского и послесталинского времени," the authors argue that the Soviet agrarian system represents a unique form of Soviet state capitalism. Although not the first to raise the issue of state capitalism in relation to the Soviet economy, the authors offer their own interpretation of state capitalism by introducing the concept of "capitalized" rather than "capitalist" into their analysis. According to them, state capitalism represents a socio-economic system in which capital or the materialized labor of the past embodied in machines and mechanisms (that is, the means of production and objects of labor), becomes a leading factor in the process of production at the expense of the diminishing role of man power (or in the authors' own terminology "live labor"). In other words, "state capitalism," in the authors' interpretation, means a capitalized (капитализированный) rather than a capitalist (капиталистический) system. In this regard, the editors wish to raise the question of whether the notion of "Soviet capitalized economy" might have served the authors as a better term to capture their analytical intervention. ${ }^{7}$

7 See their Аграрный строй России 1930-1980-х годов (М., 2014) where the concept is more thoroughly developed and the authors use the term capitalized (капитализированный) rather than capitalist (капиталистический). 
Drawing on a wide and diverse variety of sources, Beznin and Dimoni argue that the beginning of the 1960 s marks the establishment of state capitalism in the Soviet agrarian system; this was a time when the capital embodied in machines and mechanism began to account for more than 50 percent of the cost of agrarian production, thus exceeding the share of man power ("live labor"). The article contributes to the ongoing discussion of the role of collectivization in funding Soviet industrialization. ${ }^{8}$ In the authors' view, the kolkhoz system, established in the USSR in the 1930s, was a key factor in the process of the capitalization of the agrarian sector of the Soviet economy. It provided for a transition from an individualized peasant economy, with a predominance of "live labor", to an industrialized society where capital became a major factor of production. The article also examines other major characteristics of Soviet state capitalism in the agrarian sector: mechanisms of exploitation, the role of different economic uklads, the emergence of new classes, changes in the cultural landscape and ways of life of the countryside.

Svetlana Rafikova takes us into the postwar "Thaw" period and demonstrates how research situated at the intersection of economic, everyday, and oral history can help a researcher question the prevailing master-narratives scholars assign to the Soviet postwar decades. In her “'Оттепель': экономика и повседневность," a dense synthetic essay, Rafikova uncovers a complex and, presently, still not thoroughly studied interplay between changes in Soviet economic policy, the positive and negative dynamics of the postwar Five Year Plans, the growing and variable income structures of the Soviet population, the gradual building of the Soviet welfare system, and, finally, Soviet citizens' subjective perception of their economic circumstances between the early 1950s and late 196os. Her analysis constantly moves between the "center" and the Siberian "periphery," one of the largest and strategically most important regions of the Soviet Union. Among her several historiographical interventions is the proposition to rethink the Thaw period as a complex economic event. This proposition allows Rafikova, for example, to begin her "Thaw" history not with the liberalizing reforms and the Secret Speech but with the reorientation of the Soviet economy toward the consumer and the stages this complex process involved. ${ }^{9}$

8 For the best account of the discussion and new contributions to the debate see: Allen, Farm to Factory, ibid.

9 For a full explication of Rafikova's analysis, see her dissertation, С.А. Рафикова, “Повседневная жизнь сибирских горожан в 1960-е годы," Институт истории СО РАН (Новосибирск, 2013). 
Yuri Bokarev's “Динамика экономического пространства постсоветской России" introduces the SPSR reader to the field of economic space studies (исследования экономического пространства). A pioneering scholar of the 1920 s peasant household economy and its interplay with the state-run economic sector, Bokarev now turns to the problem of Russia's post-Soviet economic development. ${ }^{10}$ What distinguishes his work from the rather static approach that prevails in contemporary economic space studies is his emphasis on quickly changing dynamics within Russia's post-Soviet development. Thus, in his essay, Bokarev demonstrates how Russia's loss or re-accessions (the Crimea, for example) of territories caused by the collapse of the united economic space of the USSR produced economic and social processes that have led to the formation of a new interregional economic space. Distinguishing three major periods (1991-1993 - chaos; 1993-1998-reorganization and stabilization, 1998-present - the creation of new center-regional relations and territorial expansion), Bokarev draws a dramatic picture of ongoing transformations that, having started with the contraction, fragmentation of Soviet economic space, and depopulation (опустынивание) of provinces and periphery, have resulted in the new restructured, expanded, and regulated economic space of today's Russia.

10 Seе, Ю. П. Бокарев, Социалистическая промышленность и мелкое крестьянское хозяйство в СССР в 2о-е годы : Источники, методы исследования, этапы взаимоотношений (М.: Наука, 1989). 